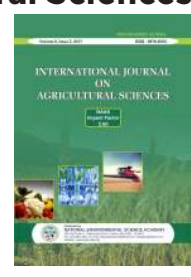

\title{
STUDIES ON FOLIAR APPLICATION OF POTASSIUM NITRATE ON PHYSIOLOGICAL, BIOCHEMICAL AND YIELD POTENTIAL IN DIFFERENT WHEAT [TRITICUM AESTIVUM L.] CULTIVARS UNDER TWO CONDITIONS
}

\author{
Swati Agrawal ${ }^{1}$, Vinaya Kumar Yadav $^{1}$, A. K. Verma $^{2}$ and R.C. Mishra ${ }^{1}$ \\ ${ }^{1}$ Swami Vivekanand University, Sagar (M.P.) India \\ ${ }^{2}$ Government P.G. College, Saidabad, Prayagraj (U.P.) India \\ Swami Vivekanand University, Sagar (470001)
}

\begin{abstract}
The field experiments were conducted at Student Instructional Farm of SVNU Sagar, during Rabi 2018-19 and 201920. The objective of investigation was to study the effect of foliar applied potassium nitrate with different doses on plant traits (physiological, biochemical, yield and its components) of two wheat varieties under drought and irrigated condition. It was designed in split-split plot design with three replications. The two conditions i.e., drought $\left(\mathrm{I}_{0}\right)$ and irrigated $\left(\mathrm{I}_{1}\right)$ conditions were allocated in the main plots and two wheat varieties i.e., $\mathrm{V}_{1}(\mathrm{~K}-402)$ and $\mathrm{V}_{2}(\mathrm{~K}-607)$ in sub plot and for each one chemical treatments were applied as foliar spray at heading stages by $0.5 \%\left(\mathrm{~T}_{1}\right)$ and $1.0 \%$ $\left(\mathrm{T}_{2}\right)$ potassium nitrate, along with control $\left(\mathrm{T}_{0}\right)$ in sub-sub plots. The significantly higher grain yield (5.84 \& $5.88 \mathrm{~g}$ ) with physiological, biochemical and yield traits can be obtained by foliar application of $0.5 \%$ potassium nitrate $\left(\mathrm{T}_{1}\right)$ with both conditions of i.e., drought $\left(\mathrm{I}_{0}\right)$ and irrigated $\left(\mathrm{I}_{1}\right)$ of wheat crop. In this were represent $0.5 \%$ potassium nitrate $\left(\mathrm{T}_{1}\right)$ i.e., 5.31 \& $5.27 \mathrm{~g}, 1.0 \%$ potassium nitrate $\left(\mathrm{T}_{2}\right)$, as compare to control $\left(\mathrm{T}_{0}\right)$ i.e., 4.39 \& $4.35 \mathrm{~g}$. In cultivars, maximum responsive was $\mathrm{K}-402\left(\mathrm{~V}_{1}\right)$ in most of traits and gave significantly higher grain yield (5.88 \& $\left.5.84 \mathrm{~g}\right)$ and minimum in K-607 $\left(\mathrm{V}_{2}\right)$ i.e., 5.80 \& $5.54 \mathrm{~g}$ with both concerning experimental years.
\end{abstract}

Keywords: Physiological, biochemical, yield attributes, foliar spray of thio-urea on drought and irrigated conditions.

\section{INTRODUCTION}

Wheat consumption worldwide is estimated to 817 million tons by 2030 and production would need to increase at 22.6-43.6\% in different countries at the current production level to meet the estimated consumption demand India is the largest wheat producing country in the world after China. The wheat production has increased manifold from 6.60 million tonnes at the time of independence to 107.86 million tons in (Anonymous, 2019-20). The productivity has witnessed an increase by 473 per cent i.e. from 670 $\mathrm{kg} / \mathrm{ha}$ to $3533 \mathrm{~kg} / \mathrm{ha}$ during the above period. Despite delayed sowing, the country recorded 38.99 million hectares. The clearly indicates the strength of systematic and planned wheat research in the country.Theclearly indicates the strength of systematic and planned wheat research in the country. Wheat consumption in India estimated to surpass 110 million tons of wheat will be needed by 2020.

(Slefer and Rawson, 1994)Wheat is basically a Rabi crop that needs cool winter and hot summers for its well growth and development, that's why it is extensively grown in countries with tropical and subtropical climates. The productivity and yield of wheat is significantly influenced by selection of suitable varieties, soil and environmental conditions as well as the management practices. Higher 
productivity of wheat mainly depends on biomass productivity and harvest index. Biomass potential of a genotype is achieve when growth and development phases match with the congenial environmental and management conditions. Wheat is a long day crop and requires relatively low temperature and photoperiod play a key role in determining duration of different phonological phases, which affect the vegetative and reproductive development and yield.

Major threat to reduce growth and yield of a plant is drought stress. This shortage of water occurs in region of low rainfall, and most wheat is cultivated in such semi-arid regions. Nutritional status of the plant is the indicator of its response to environmental stress. (Deng et al., 2004) reported that potassium enhanced drought tolerance in plants by mitigating harmful effects by increasing translocation and by maintaining water balance. Crop can more easily take nutrients when applied foliar and in return crop yield increased. (El-Ashryet al., 2005) reported that the negative effect of drought on growth of wheat can be decreased by spraying $\mathrm{K}$; plants translocate this $\mathrm{K}$ to all its parts, in turn yield per plant increased. Average wheat yield increased in K fertilizedplots (Pettigrew, 2008). Potassium has the major role in osmoregulation, photosynthesis, transpiration, stomata opening and closing and synthesis of protein etc. Drought is the most prevailing problem and the factor knownto be serious for its impacts on crop limitations (Souza et al., 2004). This kind of abiotic stress often occurred as consequence of the reduction of the water level that reaches earth due to extreme atmospheric conditions which frequently cause water loss via transpiration and evaporation. Generally, water scarcity resulted fromeither drought or soil salinity influenced crop plant'smorphology, physiology and could lead to cellular and organelles deformation. Drought specific impacts on biochemical and molecular processes lead to stomata closure with consecutive decrease in rates of transpiration, pigment content, photosynthesis, caused protein alterations and ended with growth inhibition.

At present, wheat growth has been seriously influenced by drought in many regions (Abdel Kader et al., 2010). Many techniques were invented to assess wheat tolerance; as such, seed priming and exogenous applications before and during cultivation were efficiently used as methods of plant mitigations under drought stress. Furthermore, glycine betaine application to plants was effective with stabilizing the quaternary structures of enzymes and complex proteins, lipids of photosynthetic apparatus and in maintaining highly ordered state of membranes. Although physiological processes that stimulated these improvements are not yet discovered, the seed priming was achieved progressively in many plant species and was potent in improving yield quality and yield amounts (Harris et al., 2002).

\section{MATERIALSAND METHODS}

All facilities related to study were available at the Experimental Research Student Instructional Farm of S. V. N. University Sagar. Geographically Sagar is located of $23.83^{\circ} \mathrm{N}$ Longitude of $78.71^{\circ} \mathrm{E}$ and above 427 meters sea level. It lies in the sub-tropical regions where wheat is grown in the Rabi seasons. A total dose of $150 \mathrm{~kg} / \mathrm{ha}$ Nitrogen, $80 \mathrm{~kg} / \mathrm{ha}$ Phosphorus and $60 \mathrm{~kg} / \mathrm{ha}$ Potash, through urea, single super phosphate (SSP) and murate of potash (MOP) were used in the experiment.

\section{Canopy temperature depression ${ }^{0} \mathrm{C}$ (CTD):}

It was measured by Infra-Red Thermo-meter. (Tele temp AG-42 USA)

a) The difference between ambient and canopy temperature has to be entered in the data book.

b) Canopy in the area earmarked for final observation may be focused for CTD measurement.

c) Care should be taken to see that the angle and the distance between the canopy and the Infra-red Thermo-meter remain constant for each plot.

d) Observation should be recorded between $11.00 \mathrm{a} . \mathrm{m}$. to 01.00 p.m. (mid-day).

\section{Chlorophyll fluorescence $\left(F_{v} / F_{m}\right)$}

Chlorophyll fluorescence was measured at pre-anthesis and 15 days after anthesis. It was determined by fluorescence measurement system (Handy PEA Hansatech Electronics Ltd. UK). Fluorescence was calculated to determine the degree of thermo inhibition (Havaux 1993, 2001).

\section{Chlorophyll content ( $\mathrm{mg} \mathrm{g}^{-1}$ )}

Chlorophyll content was measured by method given by Arnon and Stout, (1949).

\section{Protein Content (\%)}

Protein content $(\%)=$ Nitrogen content $(\%) * 5.83$ (Factor)

The experiment consisted of two conditions in main plot, drought $\left(\mathrm{I}_{0}\right)$ and irrigated $\left(\mathrm{I}_{1}\right)$, two varieties in sub plot $\left(\mathrm{V}_{1}\right)$ $\mathrm{K}-1006$ and $\left(\mathrm{V}_{2}\right) \mathrm{K}-307$, three treatments in sub-sub plot $\left(\mathrm{T}_{0}\right)$ control, $\left(\mathrm{T}_{3}\right)$ 500ppm thio-urea and $\left(\mathrm{T}_{4}\right)$ 1000ppm thiourea foliar spray at heading stage. These three treatment combinations were replicated in three replications in splitsplit plot design. Observations were recorded on physiological characteristics viz. canopy temperature depression and chlorophyll fluorescence at heading stage, biochemical parameter viz. chlorophyll content and 
protein content, yield and yield attributes viz. biological yield per plot (kg) and economical yield per plot (kg). All the data on physiological, biochemical parameters and yield contributory characters were statically analysed by the methods suggested by Fisher (1937).

\section{RESULTS AND DISCUSSION}

The physiological traits, canopy temperature depression measured highest in potassium nitrate $0.5 \%$ and potassium nitrate $1.0 \%$ with combination $3.55^{\circ} \mathrm{C}$ and $3.45^{\circ} \mathrm{C}$ and least in control $2.27^{\circ} \mathrm{C}$, chlorophyll fluorescence measured by
0.786 and 0.759 as compared to control 0.625 and relative water content was recorded 84.78 and 83.94 while least in control 81.15 for both corresponding years were nonsignificantly (Table 1). The canopy temperature depression decreased, chlorophyll fluorescence and relative water content were increase in drought condition. Water stress is generally characterized by decrease in relative water content and water potential, resulting in wilting, stomata closure and reduced growth. Earlier reports by Kaya et al., (2013) and Atiqueet al., (2014) also support these observations.

\section{Table 1: Effect on foliar application of potassium nitrate on physiological parameter.}

\begin{tabular}{|c|c|c|c|c|c|c|c|c|c|c|c|c|c|}
\hline & & & & 2018-19 & & & & & & 201 & -20 & & \\
\hline Tre & & $\begin{array}{r}\text { Canop } \\
\text { I }\end{array}$ & $\begin{array}{l}\text { y Temp } \\
\text { epressic }\end{array}$ & $\begin{array}{l}\text { rature } \\
\text { n }\end{array}$ & & $\begin{array}{l}\text { hlorophy } \\
\text { lorescen }\end{array}$ & & $\begin{array}{r}\text { Canop } \\
\text { I }\end{array}$ & $\begin{array}{l}\text { y Tempe } \\
\text { epressio }\end{array}$ & nature & & $\begin{array}{l}\text { hlorophy } \\
\text { lorescen }\end{array}$ & \\
\hline & & $\begin{array}{c}\text { Control } \\
\left(T_{0}\right)\end{array}$ & $\begin{array}{c}0.5 \% \\
\text { Potassium } \\
\text { nitrate } \\
\left(\mathrm{T}_{1}\right)\end{array}$ & $\begin{array}{c}0.1 \% \\
\text { Potassium } \\
\text { nitrate } \\
\left(\mathrm{T}_{2}\right)\end{array}$ & $\begin{array}{c}\text { Control } \\
\left(T_{0}\right)\end{array}$ & $\begin{array}{c}0.5 \% \\
\text { Potassium } \\
\text { nitrate } \\
\left(\mathrm{T}_{1}\right)\end{array}$ & $\begin{array}{c}0.1 \% \\
\text { Potassium } \\
\text { nitrate } \\
\left(\mathrm{T}_{2}\right)\end{array}$ & $\begin{array}{c}\text { Control } \\
\left(T_{0}\right)\end{array}$ & $\begin{array}{c}0.5 \% \\
\text { Potassium } \\
\text { nitrate } \\
\left(\mathrm{T}_{1}\right)\end{array}$ & $\begin{array}{c}0.1 \% \\
\text { Potassium } \\
\text { nitrate } \\
\left(\mathrm{T}_{2}\right)\end{array}$ & $\begin{array}{c}\text { Control } \\
\left(T_{0}\right)\end{array}$ & $\begin{array}{c}0.5 \% \\
\text { Potassium } \\
\text { nitrate } \\
\left(\mathrm{T}_{1}\right)\end{array}$ & $\begin{array}{c}0.1 \% \\
\text { Potassium } \\
\text { nitrate } \\
\left(\mathrm{T}_{2}\right)\end{array}$ \\
\hline I0 & $\mathrm{V}^{1}$ & 2.27 & 2.40 & 2.33 & 0.742 & 0.762 & 0.752 & 2.30 & 2.46 & 2.38 & 0.756 & 0.764 & 0.757 \\
\hline & $\mathrm{V}^{2}$ & 2.36 & 2.65 & 2.54 & 0.749 & 0.761 & 0.757 & 2.40 & 2.60 & 2.56 & 0.753 & 0.765 & 0.756 \\
\hline I1 & $\mathrm{V}^{1}$ & 3.31 & 3.39 & 3.37 & 0.628 & 0.650 & 0.645 & 3.35 & 3.42 & 3.40 & 0.635 & 0.658 & 0.652 \\
\hline & $\mathrm{V}^{2}$ & 3.38 & 3.53 & 3.46 & 0.625 & 0.655 & 0.648 & 3.40 & 3.55 & 3.50 & 0.630 & 0.660 & 0.653 \\
\hline Fac & & I & $\mathbf{V}$ & $T$ & I & $\mathbf{V}$ & $\mathrm{T}$ & I & $\mathbf{V}$ & $\mathbf{T}$ & I & $\mathbf{V}$ & $\mathbf{T}$ \\
\hline SE & & 0.07 & 0.08 & 0.06 & 0.008 & 0.006 & 0.006 & 0.03 & 0.04 & 0.06 & 0.006 & 0.001 & 0.003 \\
\hline $\begin{array}{l}\text { C.D } \\
\text { at } 5\end{array}$ & & 0.32 & NS & 0.13 & 0.035 & NS & 0.012 & 0.13 & 0.09 & 0.11 & 0.025 & NS & 0.009 \\
\hline
\end{tabular}

Table 2: Effect on foliar application of potassium nitrate on biochemical parameter.

\begin{tabular}{|c|c|c|c|c|c|c|c|c|c|c|c|c|c|}
\hline & & & & 2018-19 & & & & & & 201 & -20 & & \\
\hline Tre & & $\begin{array}{r}\text { Canop } \\
\text { I }\end{array}$ & $\begin{array}{l}\text { y Tempe } \\
\text { epressio }\end{array}$ & $\begin{array}{l}\text { erature } \\
\text { n }\end{array}$ & & $\begin{array}{l}\text { hlorophy } \\
\text { uorescen }\end{array}$ & & $\begin{array}{r}\text { Canop } \\
\text { I }\end{array}$ & $\begin{array}{l}\text { y Temp } \\
\text { epressio }\end{array}$ & erature & & $\begin{array}{l}\text { hlorophy } \\
\text { uorescen }\end{array}$ & \\
\hline & & $\begin{array}{c}\text { Control } \\
\left(T_{0}\right)\end{array}$ & $\begin{array}{c}0.5 \% \\
\text { Potassium } \\
\text { nitrate } \\
\left(\mathrm{T}_{1}\right)\end{array}$ & $\begin{array}{c}0.1 \% \\
\text { Potassium } \\
\text { nitrate } \\
\left(\mathrm{T}_{2}\right)\end{array}$ & $\begin{array}{c}\text { Control } \\
\left(\mathrm{T}_{0}\right)\end{array}$ & $\begin{array}{c}0.5 \% \\
\text { Potassium } \\
\text { nitrate } \\
\left(\mathrm{T}_{1}\right) \\
\end{array}$ & $\begin{array}{c}0.1 \% \\
\text { Potassium } \\
\text { nitrate } \\
\left(\mathrm{T}_{2}\right)\end{array}$ & $\begin{array}{c}\text { Control } \\
\left(T_{0}\right)\end{array}$ & $\begin{array}{c}0.5 \% \\
\text { Potassium } \\
\text { nitrate } \\
\left(\mathrm{T}_{1}\right)\end{array}$ & $\begin{array}{c}0.1 \% \\
\text { Potassium } \\
\text { nitrate } \\
\left(\mathrm{T}_{2}\right)\end{array}$ & $\begin{array}{c}\text { Control } \\
\left(T_{0}\right)\end{array}$ & $\begin{array}{c}0.5 \% \\
\text { Potassium } \\
\text { nitrate } \\
\left(\mathrm{T}_{1}\right) \\
\end{array}$ & $\begin{array}{c}0.1 \% \\
\text { Potassium } \\
\text { nitrate } \\
\left(\mathrm{T}_{2}\right)\end{array}$ \\
\hline I0 & $\mathrm{V}^{1}$ & 1.95 & 2.29 & 2.12 & 11.41 & 12.20 & 12.04 & 1.98 & 2.24 & 2.15 & 11.45 & 12.25 & 12.08 \\
\hline & $\mathrm{V}^{2}$ & 1.80 & 2.14 & 2.01 & 11.47 & 12.38 & 12.28 & 1.85 & 2.18 & 2.06 & 11.50 & 12.42 & 12.32 \\
\hline I1 & $\mathrm{V}^{1}$ & 1.85 & 2.24 & 2.08 & 10.30 & 11.41 & 11.35 & 1.90 & 2.28 & 2.12 & 10.35 & 11.45 & 11.38 \\
\hline & $\mathrm{V}^{2}$ & 1.76 & 2.09 & 2.02 & 10.27 & 11.32 & 11.22 & 1.80 & 2.14 & 2.06 & 10.30 & 11.36 & 11.25 \\
\hline Fac & & I & V & $\mathbf{T}$ & I & V & $\mathbf{T}$ & I & V & $\mathbf{T}$ & I & V & $\mathbf{T}$ \\
\hline SE & & 0.01 & 0.01 & 0.02 & 0.05 & 0.06 & 0.08 & 0.03 & 0.03 & 0.06 & 0.08 & 0.07 & 0.17 \\
\hline $\begin{array}{l}\text { C.D } \\
\text { at } 5\end{array}$ & & NS & 0.02 & 0.04 & 0.13 & NS & 0.17 & NS & 0.09 & 0.12 & 0.36 & NS & 0.34 \\
\hline
\end{tabular}


Table 3: Effect on foliar application of potassium nitrate on yield parameter.

\begin{tabular}{|c|c|c|c|c|c|c|c|c|c|c|c|c|c|}
\hline \multirow{3}{*}{\multicolumn{2}{|c|}{ Treatments }} & \multicolumn{6}{|c|}{ 2018-19 } & \multicolumn{6}{|c|}{ 2019-20 } \\
\hline & & \multicolumn{3}{|c|}{$\begin{array}{c}\text { Biological } \\
\text { Yield/Plot (kg) }\end{array}$} & \multicolumn{3}{|c|}{$\begin{array}{c}\text { Economical } \\
\text { Yield/Plot (kg) }\end{array}$} & \multicolumn{3}{|c|}{$\begin{array}{c}\text { Biological } \\
\text { Yield/Plot (kg) }\end{array}$} & \multicolumn{3}{|c|}{$\begin{array}{c}\text { Economical } \\
\text { Yield/Plot (kg) }\end{array}$} \\
\hline & & \multirow{2}{*}{$\begin{array}{l}\begin{array}{c}\text { Control } \\
\left(T_{0}\right)\end{array} \\
3.667\end{array}$} & \multirow{2}{*}{\begin{tabular}{|c|}
$\begin{array}{c}0.5 \% \\
\text { Potassium } \\
\text { nitrate } \\
\left(\mathrm{T}_{1}\right)\end{array}$ \\
4.267 \\
\end{tabular}} & \multirow{2}{*}{\begin{tabular}{|c|}
$\begin{array}{c}0.1 \% \\
\text { Potassium } \\
\text { nitrate } \\
\left(\mathrm{T}_{2}\right)\end{array}$ \\
4.167 \\
\end{tabular}} & \multirow{2}{*}{$\begin{array}{l}\begin{array}{c}\text { Control } \\
\left(T_{0}\right)\end{array} \\
0.425\end{array}$} & \multirow{2}{*}{\begin{tabular}{|c|}
$\begin{array}{c}0.5 \% \\
\text { Potassium } \\
\text { nitrate } \\
\left(\mathrm{T}_{1}\right)\end{array}$ \\
0.467 \\
\end{tabular}} & \multirow{2}{*}{$\begin{array}{c}\begin{array}{c}0.1 \% \\
\text { Potassium } \\
\text { nitrate } \\
\left(\mathrm{T}_{2}\right)\end{array} \\
0.450\end{array}$} & \multirow{2}{*}{$\begin{array}{l}\begin{array}{c}\text { Control } \\
\left(\mathrm{T}_{0}\right)\end{array} \\
3.669 \\
\end{array}$} & \multirow{2}{*}{\begin{tabular}{|c|}
$\begin{array}{c}0.5 \% \\
\text { Potassium } \\
\text { nitrate } \\
\left(\mathrm{T}_{1}\right)\end{array}$ \\
4.269 \\
\end{tabular}} & \multirow{2}{*}{\begin{tabular}{|c|}
$\begin{array}{c}0.1 \% \\
\text { Potassium } \\
\text { nitrate } \\
\left(\mathrm{T}_{2}\right)\end{array}$ \\
4.168 \\
\end{tabular}} & \multirow{2}{*}{\begin{tabular}{|l|}
$\begin{array}{c}\text { Control } \\
\left(\mathrm{T}_{0}\right)\end{array}$ \\
0.428 \\
\end{tabular}} & \multirow{2}{*}{\begin{tabular}{|c|}
$\begin{array}{c}0.5 \% \\
\text { Potassium } \\
\text { nitrate } \\
\left(\mathbf{T}_{1}\right)\end{array}$ \\
0.495 \\
\end{tabular}} & \multirow{2}{*}{\begin{tabular}{|c|}
$\begin{array}{c}0.1 \% \\
\text { Potassium } \\
\text { nitrate } \\
\left(\mathrm{T}_{2}\right)\end{array}$ \\
0.460 \\
\end{tabular}} \\
\hline I0 & $\mathrm{V}^{1}$ & & & & & & & & & & & & \\
\hline & $\mathrm{V}^{2}$ & 3.933 & 4.567 & 4.433 & 0.450 & 0.517 & 0.500 & 3.935 & 4.569 & 4.435 & 0.455 & 0.520 & 0.510 \\
\hline \multirow[t]{2}{*}{ II } & $\mathrm{V}^{1}$ & 7.000 & 8.233 & 8.167 & 1.175 & 1.675 & 1.550 & 7.100 & 8.236 & 8.172 & 1.180 & 1.680 & 1.555 \\
\hline & $\mathrm{V}^{2}$ & 6.400 & 7.700 & \begin{tabular}{|l|}
7.667 \\
\end{tabular} & 1.067 & 1.442 & 1.317 & 6.410 & 7.715 & 7.672 & 1.167 & 1.452 & 1.325 \\
\hline \multicolumn{2}{|c|}{ Factors } & I & $\mathrm{V}$ & $T$ & I & V & $\mathbf{T}$ & I & $\mathbf{V}$ & $\mathrm{T}$ & I & V & $\mathbf{T}$ \\
\hline \multicolumn{2}{|c|}{ SE (d) } & 0.29 & 0.35 & 0.29 & 0.04 & 0.05 & 0.09 & 0.07 & 0.06 & 0.14 & 0.03 & 0.01 & 0.03 \\
\hline \multicolumn{2}{|c|}{$\begin{array}{l}\text { C.D. } 0 \\
\text { at } 5 \%\end{array}$} & NS & NS & 0.58 & 0.19 & NS & 0.19 & 0.283 & NS & 0.40 & 0.12 & 0.03 & 0.08 \\
\hline
\end{tabular}

The biochemical traits as presented in Tables 2 in previous chapter. The chlorophyll content $\left(\mathrm{gm} \mathrm{g}^{-1}\right)$ and the protein content in grain (\%) were estimated non-significantly higher in potassium nitrate $0.5 \%$ and $1.0 \%$ with combination of the chlorophyll content ( $\mathrm{gm} \mathrm{g}^{-1}$ ) 2.46 and 2.30 as compared to control 1.76 in irrigated condition and the protein content in grain (\%) 12.50 and 12.38 drought condition and least in control 10.27 in irrigated condition during both experimental years. Improvement in chlorophyll due to foliar application of potassium may be ascribed the role of potassium in improving many physiological growth processes and delay plant leaves senescence as well as photosynthetic activity. Numerous studies have shown that the application of potassium fertilizer mitigates the adverse effects of drought on plant growth in barley, sunflower and rice that confirmed result. The same types of observation were also found by the studies of Saleemet al., (2011) and El-Yazied and Mady(2012) in wheat crop.

The data pertaining on yield and its attributes as presented in Tables 3 (in experimental finding), revealed that it varied significantly and non- significantly higher in potassium nitrate $0.5 \%$ and $1.0 \%$ during both the years. Economical yield per plot 1.785 and $1.610 \mathrm{~kg}$ at minimum control 0.425 $\mathrm{kg}$ in minimum drought and maximum in irrigated condition both years of experimentation. Moreover it was also observed by Taban and Erdal (2000) that under environmental stress conditions the spike length remains stable.

\section{CONCLUSION}

The results summarised as irrigated condition $\left(\mathrm{I}_{1}\right)$, variety K$607\left(\mathrm{~V}_{2}\right)$ among varieties, $0.5 \%$ potassium nitrate $\left(\mathrm{T}_{1}\right)$ among treatments were found significantly physiological i.e., canopy temperature depression ${ }^{0} \mathrm{C}$ (CTD), chlorophyll fluorescence and relative water content (RWC), biochemical traits i.e., chlorophyll content( $\left.\mathrm{mg} \mathrm{g}^{-1}\right)$ and protein content (\%). The summarised as irrigated condition $\left(\mathrm{I}_{1}\right)$, variety K$402\left(\mathrm{~V}_{1}\right)$ among varieties, $0.5 \%$ potassium nitrate $\left(\mathrm{T}_{1}\right)$ among treatments were found significantly superior for most of yield components i.e., biological yield plot ${ }^{-1}$, economical yield plot $^{-1}$, after harvesting were examined significant also for irrigated condition $\left(\mathrm{I}_{1}\right)$ and $0.5 \%$ potassium nitrate $\left(\mathrm{T}_{3}\right)$ but variety K-607 $\left(\mathrm{V}_{2}\right)$ for yield purpose and other traits in $\left(\mathrm{V}_{1}\right) \mathrm{K}-402$ variety during both corresponding years.

Finally, it may be concluded that significantly higher grain yield plant ${ }^{-1}$ in g (5.31 and 5.27) with best physiological, biochemical and yield traits can be obtained by foliar application of potassium nitrate $0.5 \%\left(\mathrm{~T}_{1}\right)$ with both condition of sowing in the both years i.e., irrigated $\left(\mathrm{I}_{1}\right)$ and drought $\left(\mathrm{I}_{0}\right)$ of wheat crop. Next to this were $1.0 \%$ potassium nitrate $\left(\mathrm{T}_{2}\right)$ i.e., 5.05 and $5.03 \mathrm{~g}, 0.5 \%\left(\mathrm{~T}_{1}\right)$ i.e., 4.84 and $4.80 \mathrm{~g}$, as compare to control $\left(\mathrm{T}_{0}\right)$ i.e., 4.39 and $4.35 \mathrm{~g}$. Among cultivars, maximum responsive was K-607 $\left(\mathrm{V}_{2}\right)$ in most of traits and gave significantly higher biological yield 4.80 and $4.76 \mathrm{~g}$ minimum in $\mathrm{K}-402\left(\mathrm{~V}_{1}\right)$ i.e., 4.77 and $4.73 \mathrm{~g}$ with both concerning experimental years. 


\section{REFERENCES}

1. Abdel Kader A.F., Hassanein R.A., Abo-Aly M.M., Attia M.S. and Bakir E.M. (2010).Screening the biosafety of wheat produced from pretreated grains to enhance tolerance against drought using physiological and spectroscopic methods. Food ChemlToxicol; 48:1827-1835.

2. Anonymous (2019).ICAR- Indian Institute of Wheat and Barley Research, Karnal.Annual Reports 201920.

3. Arnon D.I. and Stout P.R. (1949). The essentiality of certain element inminute quantity for plant with special reference to copper.PlantPhysiol., 14, 371375.

4. Atique-ur-Rehman, Muhammad Farooq Ahmad and Nawaz Riaz Ahmad(2014). Influence of boron nutrition on the rice productivity,kernel quality and biofortification in different production systems. Field Crops Research; 169:123-131.

5. Deng, $X$., Shan L., Inanaga $S$. and Inoue $M$. (2004). Water - saving approaches for improving wheat production. J. Sci. Food and Agri; 85(8): 13791388.

6. El-Ashry., Soad $M$. and El-Kholy M.A. (2005).Response of wheat cultivars to chemical desiccants under water stress conditions. J. Appl. Sci. Res;1(2):253-262.

7. El-Yazied, A. A. and Mady, M. A. (2012).Effect of boron and yeastextract foliar application on growth, pod setting and both green pod and seed yield of broad bean (Viciafaba L.). The Journal ofAmerican Science; 8(4):517-533.

8. Fisher R.A. (1937). Statistical analysis. Oliver Boyed. London andEdinurg.

9. Harris D., Rashid A., Hollington P.A., Jasi L. and Raches C. (2002).Prospects of improving maize yields with on-farm seed priming. In: Sustainable Maize Production Systems for Nepal. (Eds.): N.P. Rajbhandari, J.K. Ransom, K. Adikhari, A.F.E. Palmer. NARC and Cimmyt, Kathmandu, pp. 180185.
10. Havaux M. (1993). La fluorescence de la chlorophyllein vivo: quelques concepts appliqués à l'étude de la résistance de la photosynthèse aux contraintes de l'environnement : In : INRA, Les colloques. Tolérance à la sécheresse des céréales en zone méditerranéenne, Diversitégénétiqueetamélio rationvariétale 64:1-19.

11. Havaux M. and Kloppstech K. (2001). The protective functions of carotenoidand flavonoid pigments against excess visible radiation at chilling temperature investigated in Arabidopsis npq and $t t$ mutants. Planta 213: 953-966.

12. Kaya C., Sonmez O., Aydemir S., Ashraf M. and Dikilitas M. (2013). Exogenous application of mannitol and thiourea regulates plant growth and oxidative stress responses in salt-stressed maize (Zea mays L.). Journal of Plant Interactions; 8(3): 234-241.

13. Pettigrew W. T. (2008). Potassium influences on yield and quality production for maize, wheat, soybean and cotton. Plant Physiology; 133: 670-681.

14. Saleem M., Khanif Y.M., Ishak F., Samsuri A.W. and Hafeez B. (2011). Importance of boron for agriculture productivity: A Review. Int.Res. J Agric Sci. Soil Sci.1(8): 293-300.

15. Slefer G. A. and Rawson H. M. (1994).Sensitivity of wheat phasic development to major environment factors: a re-examination of some assumption made by physiologists and modelers. Aust. J.Plant Physiology; 21:393-426.

16. Souza R.P., Machado E.C., Silva J.A., Lagoa M. M. A. and Silveira J.A.G. (2004).Photosynthetic gas exchange, chlorophyll fluorescence and some associated metabolic changes in cowpea (Vignaunguiculata) during water stress and recovery. Environ. Exp. Botany; 51: 45-56.

17. Taban, S. and Erdal, I. (2000). Effects of boron on growth of various wheat cultivars and distribution of boron in aboveground parts. [Turkish] Turkish Journal of Agriculture \& Forestry. 24(2):255-262. 